\title{
INEQUALITIES OF FURUTA AND MOND-PEČARIĆ
}

\author{
Jadranka Mićić, Yuki SEO, Sin-Ei TAKahasi and MaSARU Tominaga
}

Abstract. Furuta gives extensions of inequalities due to Ky Fan and Mond-Pečarić which are associated with Hölder-McCarthy and Kantorovich type inequalities. In this paper, inspired by Furuta's idea, we shall generalize a theorem by Mond-Pečarić on the converse of Jensen's inequality. It explains us Furuta's generalizations well. As applications, we shall show general difference and ratio inequalities that can be given for several positive operators on a Hilbert space and give the explicit expressions in their estimations.

Mathematics subject classification (1991): 47A63.

Key words and phrases: operator inequality, Kantorovich inequality, Jensen's inequality.

\section{REFERENCES}

[1] Ky Fan, Some matrix inequalities, Abh. Math. Sem. Univ. Hamburg, 29 (1966), 185-196.

[2] M. FujII, T. Furuta, R. NAKAMOTO AND S.-E. TAKAHASI, Operator inequalities and covariance in noncommutative probability, Math. Japon., 46 (1996), 317-320.

[3] M. FujII, S. Izumino, R. NAKAmoto AND Y. SEO, Operator inequalities related to Cauchy-Schwarz and Hölder-McCarthy inequalities, Nihonkai Math.J., 8 (1997), 117-122.

[4] J. I. FUJII AND Y. SEO, On parametrized operator means dominated by power ones, preprint.

[5] T. FURUTA, Extensions of Mond-Pečarić Generalization of Kantorovich inequality, preprint.

[6] T.FuRUTA, Two extensions of Ky Fan generalization and Mond-Pečarić matrix version generalization of Kantorovich inequality, preprint.

[7] T. FuRUTA, Extensions of Hölder-McCarthy and Kantorovich inequalities and their applications, Proc.Japan Acad., 73, Ser. A (1997), 38-41.

[8] T. FuRUTA, Operator inequalities associated with Hölder-McCarthy and Kantorovich inequalities, J. Inequal. Appl., 2 (1998), 137-148.

[9] B. Mond AND J. E. PEČARIĆ, Convex inequalities in Hilbert space, Houston J.Math., 19 (1993), 405-420.

[10] B. Mond, J. E. PEČARIĆ, Convex Inequalities for Several positive Operators in Hilbert Space, Indian J. Math. 35, 1993, 121-135.

[11] B. MOND AND J. E. PEČARIĆ, On Jensen's inequality for operator convex functions, Houston J.Math., 21 (1995), 739-753.

[12] B. Mond, J. E. PEČARIĆ, Matrix Version of the Ky Fan Generalization of the Kantorovich Inequality II, Linear and Multilinear Algebra 38 (1995), 309-313.

[13] B. Mond, J. E. PeČArić, Some Matrix Inequalities of Ky Fan Typa, Tam. J. Math. 26, No 4, 1995, 321-326.

[14] B. Mond, J. E. PeČArić, Matrix Inequalities holds Convex Functions, J. Math. Anal. Appl. 209, 1997, 147-153.

[15] F. Riesz and B. Sz. Nagy, Functional Analysis, Translated from the 2nd French edition by Leo F. Boron (1955), Frederick Ungar Publ. Co.

[16] S.-E.TAKahasi, M.TsuKada, K.TANAHASHi AND T.OgIWARA, An inverse type of Jensen's inequlity, to appear in Math. Japon. 